\title{
Sulphur fertilization on biochemical constituents of cabbage (Brassica oleracea var. capitata. L) in non-calcareous soil of Coimbatore district, Tamil Nadu
}

\section{S. Roshini*}

Department of Soil Science and Agricultural Chemistry, Tamil Nadu Agricultural University, Coimbatore (Tamil Nadu), India

\section{Jegadeeswari}

Department of Soil Science and Agricultural Chemistry, Tamil Nadu Agricultural University, Coimbatore (Tamil Nadu), India

\section{T. Chitdeshwari}

Department of Soil Science and Agricultural Chemistry, Tamil Nadu Agricultural University, Coimbatore (Tamil Nadu), India

\section{A. Sankari}

Department of Vegetable Science, HC\& RI, Tamil Nadu Agricultural University, Coimbatore (Tamil Nadu), India

${ }^{*}$ Corresponding author. Email: sroshinirose@gmail.com

\section{Article Info}

https://doi.org/10.31018/ jans.v13i4.3063

Received: September 26, 2021

Revised: November 8, 2021

Accepted: November 12, 2021

\section{How to Cite}

Roshni, S. et al. (2021). Sulphur fertilization on biochemical constituents of cabbage (Brassica oleracea var. capitata. L) in non-calcareous soil of Coimbatore district, Tamil Nadu. Journal of Applied and Natural Science, 13(4), 1332 - 1338. https:// doi.org/10.31018/jans.v13i4.3063

\begin{abstract}
Sulphur is the fourth most important plant nutrient after nitrogen, phosphorus, and potassium, and it is becoming increasingly crucial in high-quality crop production (Bhoyar., 2019). Since limited work has been carried out regarding different sulphur sources on cabbage production in the Coimbatore district, the present study was undertaken to investigate the sulphur sources and levels on various biochemical constituents of cabbage. Hence a field experiment was conducted in the farmer's field at Viraliyur village, Thondamuthur block of Coimbatore district, Tamil Nadu to assess the effect of sulphur fertilization on improving the biochemical constituents of cabbage hybrid Saint. There were four different $S$ sources (Elemental sulphur, Potassium sulphate, Gypsum, Single super phosphate) applied at five levels (0, 20, 40,60 and $\left.80 \mathrm{~kg} \mathrm{ha}^{-1}\right)$ and replicated thrice in a factorial randomized block design. The crop was fertilized with a Soil Test Crop Response-prescribed dose of NPK (200:125:25 kg ha$\left.{ }^{1}\right)$. The crop was harvested on $90^{\text {th }}$ day and cabbage heads were analysed for various biochemical constituents like ascorbic acid, total soluble solids (TSS), titratable acidity (TA), chlorophyll content, glucosinolates (GLs), total phenol content (TPC), sulphur containing amino acid (methionine) and antioxidant enzyme activity (peroxidase). The influence of $S$ fertilizers on biochemical constituents increased significantly with increasing levels of sulphur fertilization up to $80 \mathrm{~kg} \mathrm{~S}^{-1} \mathrm{excluding}^{-1}$ ascorbic acid content. The pooled data showed that gypsum applied at $80 \mathrm{~kg} \mathrm{ha}^{-1}$ registered the maximum GLs $\left(69.0 \mu \mathrm{mol} \mathrm{g} \mathrm{g}^{-1}\right)$, TPC $\left(31.9 \mathrm{mM} 100 \mathrm{~g}^{-1}\right)$, methionine $(32.3 \%)$, peroxidase activity $\left(0.70\right.$ units $\left.\mathrm{min}^{-1} \mathrm{mg}^{-1}\right)$, TSS $\left(7.64{ }^{0} \mathrm{Brix}\right)$, TA $(0.64 \%)$, ascorbic acid

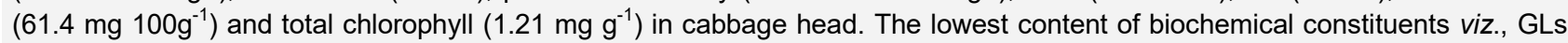
$\left(34.1 \mu \mathrm{mol} \mathrm{g}{ }^{-1}\right)$, TPC $\left(8.10 \mathrm{mM} 100 \mathrm{~g}^{-1}\right)$, methionine $(17.6 \%)$ and peroxidase $\left(0.31\right.$ units $\left.\mathrm{min}^{-1} \mathrm{mg}^{-1}\right)$ were observed in control applied NPK alone. There were positive and significant changes in the biochemical constituents of cabbage due to $S$ application which confirms the improvement in the quality of cabbage head. The study concluded that gypsum was the better sulphur source for improving the quality of cabbage.
\end{abstract}

Keywords: Biochemical constituents, Cabbage, Levels, Sources, Sulphur

\section{INTRODUCTION}

In India, nearly $42 \%$ of the cultivated soils are deficient in available sulphur (S) and good yield responses to $S$ application have been reported by Prasad and Shivay.,2017 Sulphur plays a key role in improving the growth, production, productivity, and quality of crops (Bhat et al.,2017). After nitrogen, phosphorus and po- 
tassium, the sulphur is considered the fourth important macronutrient (Jamal et al., 2010) which is required for normal growth of plants. Sulphur is regarded as an essential nutrient for protein metabolism, synthesis of oil and formation of amino acids (Krishnamoorthy, 1989) and it is one of the constituents of essential amino acids such as cysteine $(26 \%$ S), cystine $(27 \%$ S) and methionine $(21 \% \mathrm{~S})$ and thus in proteins, (Hunashikatti et al., 2000a; Singh et al, 2017; Verma and Nawange 2015).

Cabbage is one of the significant and nutritious winter cruciferous leafy vegetables grown widely in India. It contains important vitamins, minerals, and trace amounts of protein, all of which have a better caloric value. White cabbage (Brassica oleracea var. capitata L.) is consumed worldwide and is considered a good source of bioactive phytochemicals. Sulphur application is necessary to increase production and productivity while also improving cabbage quality (Bhat et al., 2017). The content of glucosinolates is affected by several environmental factors such as temperature, light, soil type and fertilizer applications (Martínez-Ballesta et al., 2013)

Brassica crop contains high sulphur content relative to other crops, and a lack of sulphur reduces crop productivity and quality. Its uptake and distribution is controlled in response to changes in nutrient demand (Yoshimoto et al., 2003; Buchner et al., 2004). Sulphur performs as primary and secondary component of cysteine and methionine synthesis, Vit $B_{1}$ and $H$, enzymes and coenzymes (Prasad. \& Shivay, 2017). Sulphur application lowers the soil pH there by increasing the availability of several essential nutrients and results in the activation of number of enzymes, energy transformation, chlorophyll formation and carbohydrate metabolism (Bairwa et al., 2017). Since, Indian soils are deficient in available sulphur, the requisite quantity for different crops needs to be applied as sulphur fertilization through various sources and levels. Cabbage is one of the preferred vegetables and sulphur loving crop which ought to be supplied with sulphur for its normal growth, yield and quality. Hence, this study was carried out with various levels of sulphur sources to assess the changes in biochemical constituents in the cabbage head to determine the quality improvement.

\section{MATERIALS AND METHODS}

\section{Field experiment}

To study the impact of various sources and levels of sulphur on various biochemical constituents, a field experiment with cabbage (Brassica oleracea var. capitata. L) was conducted in a farmer's field at Viraliyur, Thondamuthur, Coimbatore district, Tamil Nadu, during rabi season in the year of February to May 2020. The initial soil analysed was red sandy loam in texture with deficient $\mathrm{S}$ and low organic carbon and having $\mathrm{pH}$ 8.1.
Cabbage hybrid Saint was supplemented with four different $S$ sources viz., elemental sulphur, potassium sulphate, gypsum and single super phosphate (SSP) applied at five levels as $0,20,40,60$ and $80 \mathrm{~kg} \mathrm{ha}^{-1}$ which were replicated thrice in Factorial randomised block design (FRBD). The crop was fertilized with the STCR prescribed dose of NPK (200:125:25 kg ha-1) by following standard cultural practices as outlined by TNAU (HPG, 2020) and the crop was harvested on the $90^{\text {th }}$ day. Cabbage head was collected from all the treatments and analysed for biochemical constituents such as ascorbic acid, total soluble solids, titratable acidity, chlorophyll content, glucosinolates, total phenol content, sulphur-containing amino acid (methionine) and antioxidant enzyme (peroxidase). The details of experimental techniques and methodology used for individual parameters were described below.

\section{Analysis of biochemical (quality) constituents Ascorbic acid}

Ascorbic acid content was estimated by the titrimetric method using 2, 6-dichlorophenol indophenol dye. The Appearance of light pink colour shows the presence of ascorbic acid content. It is expressed as $\mathrm{mg}^{100 \mathrm{~g}^{-1} \text { of }}$ the fresh sample as outlined by Pearson (1976).

\section{Titratable acidity}

Titratable acidity was determined by using the methodology described by Instituto Adolfo Lutz (2008) and expressed in percentage.

\section{Total soluble solids (TSS)}

Finely chopped cabbage heads were macerated and the extracted juice was filtered and volume was made up to $250 \mathrm{ml}$. Total soluble solids were assessed using a hand refractometer and represented by ${ }^{\circ}$ Brix.

\section{Chlorophyll pigments}

Total chlorophyll content was estimated using the method proposed by Arnon (1949). Fifty milligrams of fresh leaf material was homogenized with $5 \mathrm{ml}$ of acetone centrifuged @ 2000 rpm for 10 minutes and volume was made up to $10 \mathrm{ml}$. The absorbance of the supernatant was measured at 645 and $663 \mathrm{~nm}$ using a Spectrophotometer (Systronics, India) and the total chlorophyll content was calculated and expressed as $\mathrm{mg} / \mathrm{g}$ of fresh weight.

\section{Total phenols}

Total phenols content was determined by Bray and Thorp's technique (1954), in which fresh leaf samples along with ethanol was heated, cooled and centrifuged at $5000 \mathrm{rpm}$. Sodium carbonate and Folin's reagents were added and estimated colorimetrically at $660 \mathrm{~nm}$. Standards were prepared using catechol at different concentrations and total phenols content was estimated 
Roshni, S. et al. / J. Appl. \& Nat. Sci. 13(4), 1332 - 1338 (2021)

and expressed in $\mathrm{mg} \mathrm{g}^{-1}$.

\section{Glucosinolates}

Homogenized $0.1 \mathrm{~g}$ dry sample in a vial with $80 \%$ methanol and centrifuged at 3000 rpm and kept overnight at ambient temperature. Then the supernatant was made up with $80 \%$ methanol. To $100 \mu$ of extract, $0.3 \mathrm{ml}$ double distilled water and $3 \mathrm{ml}$ of $2 \mathrm{mM}$ sodium tetrachloropalladate $(58.8 \mathrm{mg}$ Sodium tetrachloropalladate $+170 \mu$ concentrated $\mathrm{HCl}+100 \mathrm{ml}$ double distilled water) were added. After incubation at ambient temperature for $1 \mathrm{hr}$, absorbance was spectrophotometrically computed at $425 \mathrm{~nm}$ and the total glucosinolates was calculated (Mawlong et al., 2017).

\section{Methionine}

The Nitroprusside sodium method, the simplest method for the photometric determination of methionine suggested by McCarthy and Sullivan (1941) was followed. One $\mathrm{ml}$ of $14.3 \mathrm{M}$ sodium hydroxide solution, $1 \mathrm{ml}$ of $1 \%$ glycine solution and $0.3 \mathrm{ml}$ of $10 \%$ nitroprusside sodium solution were added to $5 \mathrm{ml}$ of the test solution, placed in a water bath at $35-40^{\circ} \mathrm{C}$ for 5 to 10 minutes, cooled with a mixture of water and ice at $0^{\circ} \mathrm{C}$. Five $\mathrm{ml}$ of a mixture of hydrochloric acid and phosphoric acid (8 parts of concentrated hydrochloric acid and 1 part of $85 \%$ phosphoric acid by volume) was added with constant stirring. After vigorous stirring, cooled in water and kept at room temperature for 5 to 10 minutes. The absorbance of the samples was measured at $580 \mathrm{~nm}$.

\section{Peroxidase}

Leaf samples were homogenised in a phosphate buffer, and $1 \mathrm{ml}$ of the supernatant was obtained, along with $3 \mathrm{ml}$ of $0.05 \mathrm{M}$ pyrogallol and $0.5 \mathrm{ml}$ of $30 \%$ hydrogen peroxide were added. The change in absorbance was measured at $430 \mathrm{~nm}$ for every 30 seconds upto 2 mins and the enzyme activity was calculated and expressed as units $\mathrm{min}^{-1} \mathrm{mg}^{-1}$ of sample (Sadasivam and Manickam, 1992).

\section{Statistical analysis}

The results pertaining to the study on biochemical compounds were statistically analysed using AGRESS software version 7.01. The mean values were compared using DMRT and the differences at $\mathrm{P}<0.05$ were considered to be significant.

\section{RESULTS AND DISCUSSION}

The findings of this study showed that sulphur sources and levels had, in general, a significant influence on cabbage quality, determining biochemical parameters.

\section{Effect of sulphur sources and levels on various biochemical compounds}

\section{TSS, TA, Ascorbic acid, Total Chlorophyll content}

The effect of sulphur fertilization on TSS ( ${ }^{0}$ Brix), titratable acidity (\%), ascorbic acid $\left(\mathrm{mg} 100 \mathrm{~g}^{-1}\right)$ and total chlorophyll content (mg $\mathrm{g}^{-1}$ ) of the cabbage head showed a statistically significant variation $(P<$ $0.05)$ among all sources of sulphur. The TSS ranged between 5.65 to $7.64{ }^{0}$ Brix, titratable acidity ranged from 0.23 to $0.64 \%$, ascorbic acid content was recorded between 44.1 to $61.4 \mathrm{mg} 100 \mathrm{~g}^{-1}$ and chlorophyll contents were ranged from 0.64 to $1.21 \mathrm{mg} \mathrm{g}^{-1}$, respectively. Gypsum as one of the sources of sulphur recorded the maximum mean of TSS $\left(7.02^{\circ}\right.$ Brix $)$, TA $(0.49 \%)$, ascorbic acid $\left(53.9 \mathrm{mg} 100 \mathrm{~g}^{-1}\right)$, and total chlorophyll content $\left(0.94 \mathrm{mg} \mathrm{g}^{-1}\right)$ followed by single super phosphate which recorded TSS $\left(6.47^{\circ}\right.$ Brix), TA $(0.40 \%)$, ascorbic acid (51.8 $\mathrm{mg} 100 \mathrm{~g}^{-1}$ ) and total chlorophyll $\left(0.88 \mathrm{mg} \mathrm{g}^{-1}\right.$ ) (Table 1 and 2; Fig. 1 and Fig. 2).

Further, the study revealed that among the different levels of sulphur irrespective of sources, $80 \mathrm{~kg} \mathrm{ha}^{-1}$ recorded the highest total soluble solids $\left(6.91{ }^{0} \mathrm{Brix}\right)$, titratable acidity $(0.52 \%)$ and chlorophyll content $(1.11$ $\mathrm{mg} \mathrm{\textrm {g } ^ { - 1 }}$ ), but for vitamin C (59.6 mg $\left.100 \mathrm{~g}^{-1}\right)$ which showed maximum content under $60 \mathrm{~kg} \mathrm{ha}^{-1}$ of sulphur. These observations were in accordance with Kusz-

Table 1. Effect of sulphur sources and levels on ascorbic acid content in cabbage head

\begin{tabular}{|c|c|c|c|c|c|c|}
\hline \multirow{2}{*}{$\begin{array}{l}\text { Sulphur sources / } \\
\left.\text { Levels (kg ha }{ }^{-1}\right)\end{array}$} & \multicolumn{6}{|c|}{ Ascorbic acid $\left(\mathrm{mg}^{\left.100 \mathrm{~g}^{-1}\right)}\right.$} \\
\hline & 0 & 20 & 40 & 60 & 80 & Mean \\
\hline Elemental sulphur & $44.1^{\mathrm{cd}}$ & $47.0^{c}$ & $50.3^{\mathrm{bc}}$ & $59.0^{\mathrm{ac}}$ & $52.4^{\mathrm{bc}}$ & 50.6 \\
\hline Potassium sulphate & $44.3^{\mathrm{bcd}}$ & $48.6^{\mathrm{bc}}$ & $52.9^{\mathrm{bc}}$ & $58.6 a^{b c}$ & $52.7^{\mathrm{bc}}$ & 51.4 \\
\hline Gypsum & $45.5^{\mathrm{ad}}$ & $51.0^{\mathrm{ac}}$ & $57.5^{\mathrm{ab}}$ & $61.4^{\mathrm{a}}$ & $54.2^{\mathrm{ab}}$ & 53.9 \\
\hline SSP & $44.2^{\mathrm{bd}}$ & $49.0^{\mathrm{bc}}$ & $53.0^{b}$ & $59.6^{\mathrm{ab}}$ & $53.0^{\mathrm{b}}$ & 51.8 \\
\hline Mean & 44.5 & 48.9 & 53.4 & 59.7 & 53.1 & 51.9 \\
\hline SEd & 0.47 & & 0.53 & & 1.06 & \\
\hline$C D(P=0.05)$ & 0.96 & & 1.07 & & 2.14 & \\
\hline
\end{tabular}


Roshni, S. et al. / J. Appl. \& Nat. Sci. 13(4), 1332 - 1338 (2021)

Table 2. Effect of sulphur sources and levels on total soluble solid contents in cabbage head

\begin{tabular}{lllllll}
\hline Sulphur sources I & \multicolumn{5}{c}{ Total soluble solids ( ${ }^{0}$ Brix) } \\
\cline { 2 - 7 } Levels $\left(\mathbf{k g ~ h a}^{-1}\right)$ & $\mathbf{0}$ & $\mathbf{2 0}$ & $\mathbf{4 0}$ & $\mathbf{6 0}$ & $\mathbf{8 0}$ & Mean \\
\cline { 2 - 7 } Elemental sulphur & $5.65^{\mathrm{de}}$ & $6.17^{\mathrm{d}}$ & $6.33^{\mathrm{cd}}$ & $6.38^{\mathrm{bd}}$ & $6.42^{\mathrm{ad}}$ & 6.19 \\
Potassium sulphate & $5.78^{\mathrm{ce}}$ & $6.28^{\mathrm{cd}}$ & $6.40^{\mathrm{c}}$ & $6.51^{\mathrm{bc}}$ & $6.62^{\mathrm{ac}}$ & 6.32 \\
Gypsum & $6.23^{\mathrm{ae}}$ & $6.68^{\mathrm{ad}}$ & $7.14^{\mathrm{ac}}$ & $7.39^{\mathrm{ab}}$ & $7.64^{\mathrm{a}}$ & 7.02 \\
SSP & $5.87^{\mathrm{be}}$ & $6.32^{\mathrm{bd}}$ & $6.57^{\mathrm{bc}}$ & $6.67^{\mathrm{b}}$ & $6.94^{\mathrm{ab}}$ & 6.47 \\
Mean & 5.88 & 6.36 & 6.61 & 6.74 & 6.91 & 6.50 \\
SEd & 0.04 & & 0.04 & & 0.09 & \\
CD $(\mathrm{P}=0.05)$ & 0.08 & & 0.09 & & 0.18 & \\
\hline
\end{tabular}

nierewicz et al.(2008) results, who conducted experiments on white cabbages to quantify the phenolic compounds, carotenoids, ascorbic acid, and antioxidant potential under different sources of sulphur. Sulphur forms the components of secondary metabolites, which play an important role in improving the quality of the produces. Higher chemical and biological activation of iron content in leaves might have increased the chlorophyll content (Bhat et al, 2017; Singh et al., 2017).

\section{Glucosinolates (GLs)}

The glucosinolate content in the cabbage head was significantly $(P<0.05)$ influenced by $S$ nutrition from different sources and the content varied from 34.1 to $69.0 \mu \mathrm{mol} \mathrm{g}{ }^{-1}$. Increasing levels of sulphur increased the glucosinolate contents in the cabbage head. Among the different levels of sulphur, the highest glucosinolate content of $62.5 \mu \mathrm{mol} / \mathrm{g}$ was recorded in the treatment applied with $80 \mathrm{~kg} \mathrm{ha}^{-1}$ of $\mathrm{S}$, followed by $60 \mathrm{~kg} \mathrm{ha}^{-1}$ of $\mathrm{S}$ and the lowest content of $35.3 \mu \mathrm{mol} \mathrm{g}^{-1}$ was recorded in the treatment without $S$ (Table 3 ). Among the sources of $S$, gypsum application $\left(52.1 \mu \mathrm{mol} \mathrm{g}^{-1}\right)$ recorded the maximum glucosinolate content, which was followed by SSP $\left(49.4 \mu \mathrm{mol} \mathrm{g}{ }^{-1}\right)$, potassium sulphate $(46.3 \mu \mathrm{mol} \mathrm{g}$ $\left.{ }^{1}\right)$ and elemental $S\left(43.0 \mu \mathrm{mol} \mathrm{g}^{-1}\right)$. These results are in accordance with earlier research works by Zaki et al. (2009), Bimova and Pokluda (2009), who increased the development of Brassica plants (broccoli and cabbage) by supplementing $\mathrm{N}$ and $\mathrm{S}$. Brassica plants exposed to $\mathrm{SO}_{2}$ and $\mathrm{H}_{2} \mathrm{~S}$ produced more water-soluble, non-protein thiol compounds in the shoot, which might be the reason for increased glucosinolate concentration (Buchner et al., 2004; Shahbaz et al., 2014). The increased gypsum concentration enhanced the total and indo-lyl glucosinolates in broccoli (Rangkadilok et al., 2004).

\section{Total phenol (TPC)}

Total phenols in cabbage heads were significantly $(P<$ 0.05 ) influenced by sulphur fertilization and the content varied from 8.10 to $31.9 \mathrm{mM}$ of fresh weight $\left(100 \mathrm{~g}^{-1}\right)$ (Table 4). The highest TPC in cabbage head was recorded by the sulphur level of $80 \mathrm{~kg} \mathrm{ha}^{-1}$ of sulphur applied as gypsum (31.9 mM $100 \mathrm{~g}^{-1}$ ) followed by SSP

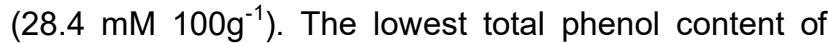

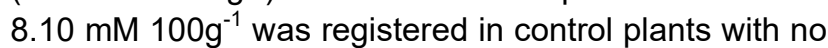
sulphur applied. Among the different sources of $\mathrm{S}$, gyp-

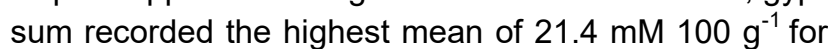
TPC followed by SSP (19.3 mM $\left.100 \mathrm{~g}^{-1}\right)$, potassium

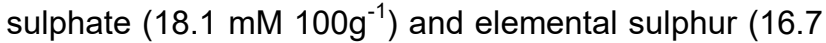
$\left.\mathrm{mM} 100 \mathrm{~g}^{-1}\right)$. The favourable effect of $\mathrm{S}$, might have enhanced the growth of cabbage seedlings and also contributed to an increase in phenolic content in cabbage head. This is in corroboration with the results of Joseph and Raj (2010) who found flavonoids and polyphenolic chemicals contained in the cabbage plant are responsible for the plant's antioxidant properties. The antiradical

Table 3. Effect of sulphur sources and levels on glucosinolates content in cabbage head

\begin{tabular}{|c|c|c|c|c|c|c|}
\hline \multirow{2}{*}{$\begin{array}{l}\text { Sulphur sources / } \\
\text { Levels }\left(\mathbf{k g ~ h a}^{-1}\right)\end{array}$} & \multicolumn{6}{|c|}{ Glucosinolates $\left(\mu \mathrm{molg}^{-1}\right)$} \\
\hline & 0 & 20 & 40 & 60 & 80 & Mean \\
\hline Elemental sulphur & $34.1^{\text {de }}$ & $37.7^{d}$ & $42.4^{\mathrm{cd}}$ & $48.2^{\mathrm{bd}}$ & $52.6^{\text {ad }}$ & 43.0 \\
\hline Potassium sulphate & $35.0^{\mathrm{ce}}$ & $38.8^{\mathrm{cd}}$ & $44.0^{c}$ & $52.1^{\mathrm{bc}}$ & $61.6^{\mathrm{ac}}$ & 46.3 \\
\hline Gypsum & $36.7^{\mathrm{ae}}$ & $44.4^{\mathrm{ad}}$ & $50.3^{\mathrm{ac}}$ & $60.2^{\mathrm{ab}}$ & $69.0^{\mathrm{a}}$ & 52.1 \\
\hline SSP & $35.4^{\text {be }}$ & $40.4^{\mathrm{bd}}$ & $46.2^{b c}$ & $58.5^{\mathrm{b}}$ & $66.7^{\mathrm{ab}}$ & 49.4 \\
\hline Mean & 35.3 & 40.3 & 45.7 & 54.8 & 62.5 & 47.7 \\
\hline SEd & 0.01 & & 0.01 & & 0.01 & \\
\hline$C D(P=0.05)$ & 0.01 & & 0.01 & & 0.02 & \\
\hline
\end{tabular}




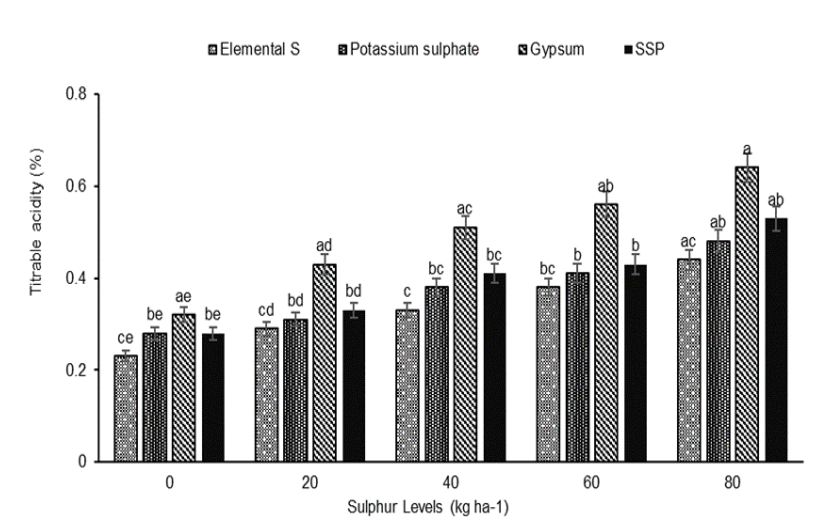

Fig. 1. Effect of different sulphur levels and sources on the titratable acidity (\%)

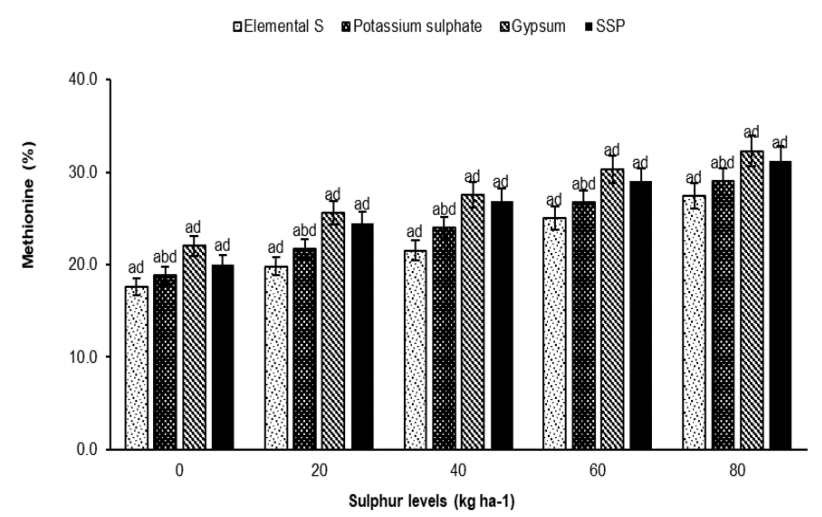

Fig. 3. Effect of different sulphur levels and sources on methionine content (\%)

scavenging activity of phenolics is associated with the substitution of hydroxyl groups in the aromatic rings of phenolics and the sulphur contributes to their hydrogen -denoting ability (Yen et al., 2005; Evans et al., 2006).

\section{Amino acids}

Similar to glucosinolates, total phenols and peroxidase, the $S$ containing amino acid, methionine were also influenced by $S$ fertilization and showed a similar trend in increasing the content due to different sources and levels of $S$. Increasing levels of $S$, increased the

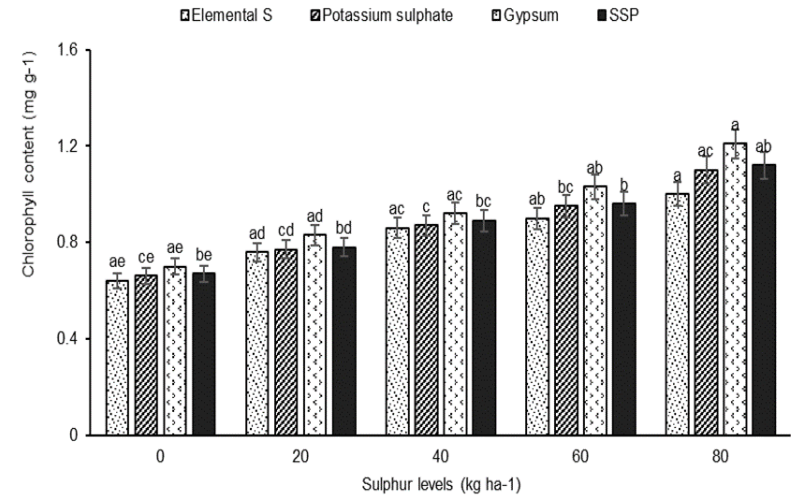

Fig. 2. Effect of different sulphur levels and sources on the chlorophyll content $\left(\mathrm{mg} \mathrm{g}^{-1}\right)$

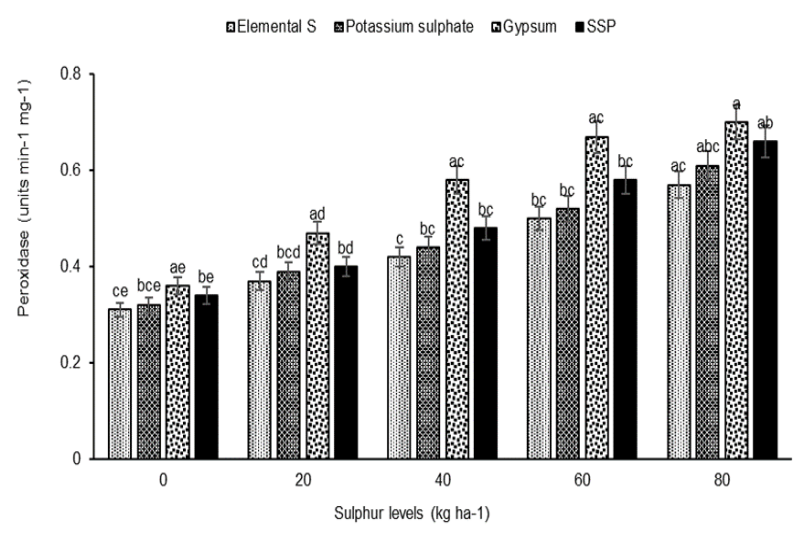

Fig. 4. Effect of different sulphur levels and sources on peroxidase activity (units $\mathrm{min}^{-1} \mathrm{mg}^{-1}$ )

methionine content and the values varied from 17.6 to $32.3 \%$ in cabbage head (Fig.3). Among the different levels applied, sulphur application @80 kg ha ${ }^{-1}$ was found superior compared to other levels. The highest methionine content of $32.3 \%$ was recorded at $80 \mathrm{~kg} \mathrm{ha}^{-}$ ${ }^{1}$ of gypsum as a source of $\mathrm{S}$ and the lowest methionine was observed in control plants (17.6\%). Among different sources, gypsum recorded the highest content of methionine $(27.9 \%)$, followed by SSP $(26.3 \%)$, potassium sulphate $(24.0 \%)$ and elemental sulphur $(22.3 \%)$. The lowest value (17.6\%) was recorded in the control

Table 4. Effect of sulphur sources and levels on total phenol content in cabbage head

\begin{tabular}{|c|c|c|c|c|c|c|}
\hline \multirow{2}{*}{$\begin{array}{l}\text { Sulphur sources I } \\
\text { Levels }\left(\mathbf{k g ~ h a}^{-1}\right)\end{array}$} & \multicolumn{6}{|c|}{ Total phenol $\left(\mathrm{mM} 100 \mathrm{~g}^{-1}\right)$} \\
\hline & 0 & 20 & 40 & 60 & 80 & Mean \\
\hline Elemental sulphur & $8.10^{\text {de }}$ & $11.9^{d}$ & $17.0^{\mathrm{cd}}$ & $21.5^{\mathrm{bd}}$ & $25.0^{\text {ad }}$ & 16.7 \\
\hline Potassium sulphate & $8.32^{\mathrm{ce}}$ & $13.1^{\mathrm{cd}}$ & $19.3^{\mathrm{c}}$ & $23.3^{\mathrm{bc}}$ & $26.5^{\mathrm{ac}}$ & 18.1 \\
\hline Gypsum & $9.90^{\mathrm{ae}}$ & $17.1^{\text {ad }}$ & $22.1^{\mathrm{ac}}$ & $26.1^{\mathrm{ab}}$ & $31.9^{\mathrm{a}}$ & 21.4 \\
\hline SSP & $8.54^{\text {be }}$ & $14.4^{\mathrm{bd}}$ & $20.4^{\mathrm{bc}}$ & $24.6^{\mathrm{b}}$ & $28.4^{\mathrm{ab}}$ & 19.3 \\
\hline Mean & 8.72 & 14.1 & 19.7 & 23.9 & 28.0 & 18.9 \\
\hline SEd & 0.03 & & 0.03 & & 0.07 & \\
\hline$C D(P=0.05)$ & 0.06 & & 0.07 & & 0.14 & \\
\hline
\end{tabular}


plot with no sulphur. Nikiforova et al. (2003) documented that brassica plants assimilate inorganic sulphate into cysteine, which is then converted to methionine. This reduction process is regulated by nitrogen. Therefore increasing sulphur supply increased the methionine content. The results of this study was in accordance with the findings of Niranjana and Devi (1990), in chilli, Hunashikatti et al. (2000b) in cabbage by using sulphur fertilization.

\section{Antioxidant enzymes}

Peroxidase activity in cabbage head was significantly $(P<0.05)$ influenced by $S$ additions and it ranged from 0.31 to 0.70 units $\mathrm{min}^{-1} \mathrm{mg}^{-1}$ (Fig.4). The sulphur application at increasing levels increased the peroxidase activity. The highest activity was observed in cabbage heads receiving $80 \mathrm{~kg} \mathrm{ha}^{-1}$ of $S$ through gypsum application $\left(0.70\right.$ units $\left.\mathrm{min}^{-1} \mathrm{mg}^{-1}\right)$ followed by $80 \mathrm{~kg} \mathrm{ha}^{-1}$ of $\mathrm{S}$ as SSP $\left(0.66\right.$ units $\left.\mathrm{min}^{-1} \mathrm{mg}^{-1}\right)$. The lowest activity was recorded in control treatment $\left(0.31\right.$ units $\mathrm{min}^{-1} \mathrm{mg}^{-}$ $\left.{ }^{1}\right)$. Out of different sulphur sources tested, gypsum recorded the highest peroxidase activity of 0.56 units $\mathrm{min}^{-1}$ $\mathrm{mg}^{-1}$ followed by SSP $\left(0.49\right.$ units $\left.\mathrm{min}^{-1} \mathrm{mg}^{-1}\right)$, potassium sulphate $\left(0.46\right.$ units $\left.\mathrm{min}^{-1} \mathrm{mg}^{-1}\right)$ and elemental sulphur $\left(0.43\right.$ units $\left.\mathrm{min}^{-1} \mathrm{mg}^{-1}\right)$. Higher activity of peroxidase and lignification increased the tolerance to pathogens. Increased peroxidase activity obstructs lipid peroxidation, breakdown of chlorophyll, ethylene synthesis, and senescence, thereby increasing quality and shelf life (Singh et al., 2010).

\section{Conclusion}

The present study concluded that sulphur played an important role in plant metabolism and the nutritional value of cabbage. Among all the $S$ sources used, gypsum was found to be the best sulphur source for improving the biochemical constituents responsible for the quality of cabbage. Sulphur supplementation through gypsum @ 80 kgha $^{-1}$ increased the biochemical constituents viz., total soluble solids, titratable acidity, total chlorophyll, glucosinolates, total phenols, methionine and peroxidase activity of cabbage head. This study revealed that $S$ fertilization helped in improving essential amino acids, soluble solids, antioxidant activity and chlorophyll pigments in cabbage which could be beneficial in improving the nutritional quality and shelf life of cabbage.

\section{ACKNOWLEDGEMENTS}

We extend our sincere gratitude and appreciation to the Micronutrient laboratory at the Department of Soil Science and Agricultural Chemistry, Tamil Nadu Agricultural University, Coimbatore, for providing laboratory facilities to carry out the research work.

\section{Conflict of interest}

The authors declare that they have no conflict of interest.

\section{REFERENCES}

1. Arnon, D.I. (1949). Estimation of chlorophyll. Plant Physiology, v. 24, p-1

2. Bairwa, R. K., Singh, S.P., Mahawar, A. K. \& Das, K. K. (2017). Influence of sulphur and spacing on growth and yield attributes of Knol-Khol (Brassica oleracea Var. Gongylodes L.) Var. early white Viana. Int. J. Curr. Microbiol. App. Sci, 6(5), 2438-2447. https://doi.org/10.20546/ ijcmas.2017.605.273.

3. Bhat, R., Rashid, Z., DaR, S. B. \& Mufti, S. (2017). Seed Yield and Quality Parameters of Cabbage (Brassica oleracea var. capitata) in relation to Different Sources and Levels of Sulphur. Current Agriculture Research Journal, 5(2), 177. http://dx.doi.org/10.12944/CARJ.5.2.04

4. Bimova, P. \& Pokluda, R. (2009). Impact of organic fertilizers on total antioxidant capacity in head cabbage. Horticultural Science, 36(1), 21-25.

5. Bray, H. G. \& Thorpe, W. V. (1954). Analysis of phenolic compounds of interest in metabolism. Methods of biochemical analysis, 27-52.

6. Buchner, P., Takahashi, H. \& Hawkesford, M. J. (2004). Plant sulphate transporters: co-ordination of uptake, intracellular and long-distance transport. Journal of experimental Botany, 55(404), 1765-1773. https://doi.or g/10.1093/jxb/erh206.

7. Martínez-Ballesta del Carmen, M., Moreno, D. A. \& Carvajal, M. (2013). The physiological importance of glucosinolates on plant response to abiotic stress in Brassica. International Journal of Molecular Sciences, 14(6), 11607-11625. https://doi.org/10.3390/ijms140611607.

8. Evans, D. A., Hirsch, J. B. \& Dushenkov, S. (2006). Phenolics, inflammation and nutrigenomics. Journal of the Science of Food and Agriculture, 86(15), 2503-2509. https://doi.org/10.1002/jsfa.2702.

9. Hunashikatti, M. G., Channal, H. T., Sarangamath, P. A., Manjunathaiah, H. M. \& Dharmatti, P. R. (2000). Effect of sulphur and molybdenum on yield and quality of cabbage. Fertiliser News, 45(8), 53-55.

10. Hunashikatti, M. G., Channal, H. T., Sarangamath, P. A., Manjunathaiah, H. M., \& Hebsur, N. S. (2000). Effect of sulphur and molybdenum on the dry matter yield and uptake of $S$ and Mo by cabbage. Karnataka Journal of Agricultural Sciences, 13(4), 840-845.

11. Jamal, A., Moon, Y. S. \& Zainul Abdin, M. (2010). Sulphur -a general overview and interaction with nitrogen. Australian Journal of Crop Science, 4(7), 523-529.

12. Joseph, B. \& Raj, S. J. (2010). Phytopharmacological properties of Ficus racemosa Linn- An overview. Int $J$ Pharm Sci Rev Res, 3(2), 134-138.

13. Krishnamoorthy, S. K (1989). Sulphur fertilization for yield and quality of crops. In Proc. National seminar on Sulphur in Agriculture, held at UAS, Bangalore. Pp 22 (Vol. 25).

14. Kusznierewicz, B., Bartoszek, A., Wolska, L., Drzewiecki, J., Gorinstein, S. \& Namieśnik, J. (2008). Partial characterization of white cabbages (Brassica oleracea var. capitata f. alba) from different regions by glucosinolates, bioactive compounds, total antioxidant activities and pro- 
Roshni, S. et al. / J. Appl. \& Nat. Sci. 13(4), 1332 - 1338 (2021)

teins. LWT-Food Science and Technology, 41(1), 1-9. https://doi.org/10.1016/j.lwt.2007.02.007.

15. LUTZ, I. A. (2008). Métodos físico-químicos para análise de alimentos. São Paulo: ANVISA.

16. Mawlong, I., Sujith Kumar, M. S., Gurung, B., Singh, K. H. \& Singh, D. (2017). A simple spectrophotometric method for estimating total glucosinolates in mustard de-oiled cake. International Journal of Food Properties, 20(12), 3274-3281. https://doi.org/10.1080/10942912.2017.1286 353.

17. McCarthy, T. E. \& Sullivan, M. X. (1941). A new and highly specific colorimetric test for methionine. Journal of Biological Chemistry, 141(3), 871-876.

18. Nikiforova, V., Freitag, J., Kempa, S., Adamik, M., Hesse, H. \& Hoefgen, R. (2003). Transcriptome analysis of sulfur depletion in Arabidopsis thaliana: interlacing of biosynthetic pathways provides response specificity. The Plant Journal, 33(4), 633-650. https://doi.org/10.1046/j.1365-313 X.2003.01657x.

19. Niranjana, K. V. \& Devi, L. S. (1990). Influence of P and S on yield and quality of chillies. Current ResearchUniversity of Agricultural Sciences (Bangalore), 19(6), 9394.

20. Pearson. D, (1976). The Chemical Analysis of Foods (7th edn). Churchill Livingstone, Edinburgh, UK

21. Prasad, R. \& Shivay, Y. S. (2017). Sulphur fertilization and food quality-A review. Indian Journal of Agronomy, 62(1), 1-7.

22. Rangkadilok, N., Nicolas, M. E., Bennett, R. N., Eagling, D. R., Premier, R. R. \& Taylor, P. W. (2004). The effect of sulfur fertilizer on glucoraphanin levels in broccoli (B. oleracea L. var. italica) at different growth stages. Journal of Agricultural and Food Chemistry, 52(9), 2632-2639. https://doi.org/10.1021/jf030655u

23. Sadasivam, S. and A. Manickam, (1992). Biochemical Methods. New age International Publishers, TNAU, Coimbatore.

24. Shahbaz, M., Stuiver, C. E. E., Posthumus, F. S., Parmar,
S., Hawkesford, M. J. \& De Kok, L. J. (2014). Copper toxicity in $C$ hinese cabbage is not influenced by plant sulphur status, but affects sulphur metabolism $\square$ related gene expression and the suggested regulatory metabolites. Plant Biology, 16(1), 68-78. https://doi.org/10.1111/ plb.12019

25. Singh, B. K., Sharma, S. R. \& Singh, B. (2010). Antioxidant enzymes in cabbage: variability and inheritance of superoxide dismutase, peroxidase and catalase. Scientia Horticulturae, 124(1),9-13. https://doi.org/10.1016/j.scient a.2009.12.011

26. Singh, M., Kushwaha, B. K., Singh, S., Kumar, V., Singh, V. P. \& Prasad, S. M. (2017). Sulphur alters chromium (VI) toxicity in Solanum melongena seedlings: role of sulphur assimilation and sulphur-containing antioxidants. Plant Physiology and Biochemistry, 112, 183-192. https://doi.org/10.1016/j.plaphy.2016.12.024.

27. Verma, H. \& Nawange, D. D. (2015). Effect of different levels of nitrogen and sulphur on the growth, yield and quality of cabbage [Brassica oleracea var. capitata L.]. Agricultural Science Digest-A Research Journal, 35 (2), 152-154. http://dx.doi.org/10.5958/0976-0547.201 5.00028 .2

28. Yen, W. J., Chang, L. W. \& Duh, P. D. (2005). Antioxidant activity of peanut seed testa and its antioxidative component, ethyl protocatechuate. LWT-Food Science and Technology, 38(3), 193 - 200. https://doi.org/10.101 6/ j.Iwt.2004.06.004

29. Yoshimoto, N., Inoue, E., Saito, K., Yamaya, T. \& Takahashi, H. (2003). Phloem-localizing sulfate transporter, Sultr1; 3, mediates re-distribution of sulfur from source to sink organs in Arabidopsis. Plant Physiology, 131(4), 1511-1517. https://doi.org/10.1104/pp.014712

30. Zaki, M.F., Abdelhafez, A.A.M., El-dewiny, Y. and Camilia. (2009). Influence of biofertilization and nitrogen sources on growth, yield and quality of broccoli (Brassica oleracea L. var.italica). Egypt. J Appl. Sci., 24, 86-111. 